\title{
EXPERIMENTAL INVESTIGATION OF THE POZZOLANIC POTENTIALS OF MILLET AND RICE HUSK ASH AS MINERAL ADDITIVE IN SELF-COMPACTING CONCRETE
}

\author{
John Wasiu*, Fashina Ayoola Oluwatosin \\ Afe Babalola University, College of Engineering, Department of Civil Engineering, P.M.B. 5454, 23400 \\ Ado-Ekiti, Ekiti state, Nigeria \\ * corresponding author: johnwasiu@abuad.edu.ng
}

\begin{abstract}
Self-compacting concrete (SCC) is a new concept of concrete mix which flows in a formwork and consolidates itself without the need for compaction. Effectively compacting concrete can be very difficult especially in areas with a high number of reinforcement. Millet Husk Ash (MHA) and Rice Husk Ash (RHA) are agricultural waste materials obtained from farm and burnt to ashes to discard them since they are environmental waste. This research is focused on finding the pozzolanic potentials of MHA and RHA as a mineral additive in SCC to see if it will improve its properties rather than discarding them as environmental waste. Laboratory investigations were carried out on normally vibrated concrete (NVC) and SCC using MHA and RHA as an additive at a $10 \%$ replacement with cement. Workability tests were carried out following the BS specifications. ASTM $293 \mathrm{C}$ was used for the Flexural Capacity test on the beam specimen. The Results of the workability tests using MHA and RHA as mineral additive are within the specified standard values. The compressive strength test also revealed that the SCC using $\mathrm{MHA}$ is about $12.8 \%$ higher than the RHA and NVC at 28 days with densities of $2487.5,2516.5$ and $2437.5 \mathrm{~kg} / \mathrm{m}^{3}$ respectively. The Modulus of Rupture (MoR) and Split Tensile strength for MHA is $0-19.2 \%$ and 17.2-22.2\% higher than the RHA and NVC respectively. It was concluded that the improvement in the pozzolanic properties of MHA and RHA may be due to the content of Lime $(\mathrm{CaO})$, Silica $\left(\mathrm{SiO}_{2}\right)$, Alumina $\left(\mathrm{Al}_{2} \mathrm{O}_{3}\right)$, Iron oxide $\left(\mathrm{Fe}_{2} \mathrm{O}_{3}\right)$ being greater than $70 \%$ and in an accordance with BS 618 code. It is concluded that the MHA and RHA can find suitable applications in the SCC as a mineral additive rather than discarding them as environmental waste.
\end{abstract}

KEYWORDS: Self-compacting concrete, millet husk ash, rice husk ash, compressive strength, workability.

\section{INTRODUCTION}

Self-Compacting Concrete (SCC) can be described as highly flowable concrete that can spread, fill and compact itself under its own weight onto every corner of a given formwork without the need of any mechanical vibration. This special concrete was first discovered in Japan in 1988 due to the dearth of skilled workers in the Japanese Construction industry. The application of SCC in the construction industry requires fewer workforces especially in the mixing, placement and compaction of concrete [1]. The Construction industries have regained confidence in terms of durability and more efficient concrete structures.

In the design, preparation and mixing of SCC, the use of water reducer cannot be overruled. Water reducers (Super plasticizer) are commonly used to enhance stability, mobility and to prevent segregation of the concrete mix. The reduction in the water content will help to increase the strength and durability of the SCC. Fillers are also employed in the SCC mix to prevent the occurrence of voids and to improve the setting time. Commonly used fillers in the SCC are fly ash, Calcium Carbonate, rice husk ash (RHA), silica fume, glass and quartzite. This research will, therefore, explore the pozzolanic properties of Rice
Husk Ash (RHA) and Millet Husk Ash (MHA) in the SCC mix.

The SCC mix design will include significant amount of fine-grained inorganic materials in their constituents and thereby increasing the possibilities for the use of mineral admixtures, which are currently agricultural waste products with no practical applications and are expensive to dispose of [2].

\section{Literature REVIEW}

The new invention behind the SCC involves the replacement of cement (partially or wholly) with fine materials (like silica fume, fly ash) without a modification to the water content. This process alters the mechanical behaviour of the concrete [3]. In general, to achieve an effective workability of the SCC concrete mix, the fine particles must be dense enough, usually about 520 to $560 \mathrm{~kg} / \mathrm{m}^{3}$ [3]. The use of stabilizers or viscosity modifying agents (VMA) is common because the SCC is very susceptible to any changes in the water content.

Based on the composition of the concrete mortar, the SCC is divided into: SCC with Powder only, SCC with VMA or SCC with a combination of both powder and VMA. Elyamany et al. 44 studied the effect of 


\section{Regular Mix}

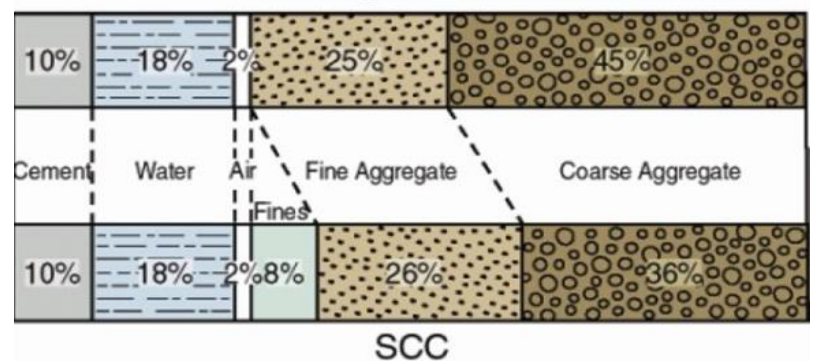

FigURE 1. Materials proportion used in regular concrete and self-compacting concrete by absolute volume [6].

filler types on physical, mechanical and microstructure of self-compacting concrete and Flowable concrete. In their research, filler materials (i.e pozzolanic and non-pozzolanic fillers) in the range of $7.5 \%-15 \%$ were used as a partial replacement for cement. Their findings revealed a significant effect of fillers on the properties of fresh and hardened concrete. The nonpozzolanic fillers have an insignificant negative effect on the properties of the SCC.

For the SCC with powder, the necessary mortar is produced by the use of a high proportion of fines while for the SCC with VMA, the proportion of fines is in the same permissible range for normally vibrated concrete (NVC). The viscosity required to inhibit the segregation will then be adjusted by using a stabilizer [5]. The combination type is created by adding a minute amount of the stabilizer to the powder type in order to balance the moisture fluctuations in the manufacturing process. This is the type adopted in this research. Mixture Proportions of the SCC by 6 as compared to normally vibrated concrete is shown in Fig. 1.

In general, the flowability of the SCC is heavily dependent on powder particle size and, in addition, on factors, such as mixing regimen and water/super plasticizer content [7, 8].

Murthi et al 9] studied the permeability properties of lightweight self-consolidating concrete made with a coconut shell aggregate. The replacement of crushed rock with a coconut shell was in the range of $0-100 \%$ in steps of $25 \%$. Their experimental investigations revealed a better performance of the coconut shell as aggregates and up to a replacement of $75 \%$.

Millet husk has not been fully explored into as a mineral additive in the construction industry [10]. However, some researchers have shown that the MHA can be used as a partial replacement of cement in concrete mix, thereby improving its properties in fresh and hardened form [11. Agricultural waste such as the MHA will provide a cost effective construction material when used as a partial replacement for cement. It will also provide a less expensive soil block construction with a proper strength being maintained [12]. The effectiveness of the RHA in concrete mix is attributed to the high amount of silica present in its ash. It contains about $85 \%$ to $95 \%$ weight percent of amorphous silica. They are found to be pozzolanic reactive material, which improves the microscopic structure of the cement paste and aggregates surface area in the SCC [13. The RHA, as partial replacement for cement in concrete mix, is also found to perform well in fire 14 .

A low-density SCC containing pumice and mineral admixtures was also studied by Arun Kumar et al [15. They applied the principle of artificial neural network for the modelling of the mechanical properties of a lightweight SCC. Their investigation yielded the best model for the tested concrete.

\section{MATERIALS AND METHODS}

The materials used in this research work includes: Ordinary Portland Cement (OPC) obtained locally from Dangote distributor, river sand (fine aggregate) and granite (coarse aggregate) obtained from Akure quarry site, mineral additives like Rice husk ash (RHA), Millet husk ash MHA) were obtained from Maiduguri, Nigeria; and chemical admixtures (superplasticizer i.e. SP430) obtained from PURECHEM. The [16 method of design was adopted in this research. The concrete was designed using the characteristic strengths of $70 \mathrm{~N} / \mathrm{mm}^{2}$. Table 1 shows the mix design ratios. All measurements are $\mathrm{kg} / \mathrm{m}^{3}$. The maximum amount of mineral additives used in this research was obtained by carrying out a trial mix design consisting of 0 $15 \%$ of the MHA and RHA in the SCC that would produce an optimum strength. The trial mix design revealed an optimum strength at $10 \%$ of the MHA and RHA as mineral additives in the SCC and this value was adopted in this research work to determine the pozzolanic potentials of both additives. The MHA and RHA was burnt in a lift out furnace at a temperature of about $650{ }^{\circ} \mathrm{C}$ for 6 hours as recommended by 17 .

The Chemical properties of the MHA and RHA obtained are presented in Table 2

Many authors have proposed a variety of test methods to assess and measure the fresh properties of the SCC. But none has proved satisfactorily well to assess all key parameters of the SCC. A brief summary of the common tests proposed by 18 in the assessment of fresh properties of the SCC and their acceptance criteria are given in Tables 3 and 4

\subsection{TEST FOR WORKABILITY}

Workability tests are carried out according to the specifications of BS EN 12350-8 [19], BS EN 123509 [20] and BS EN 12350-10 [21] respectively. The test includes slump cone, V-Funnel and L-Box Test.

In the Slump test, the materials required are the same as those used in carrying out the slump test of the NVC. However, this test method is different from the conventional slump procedure in the sense that the concrete placed inside the slump cone is not tamped and the concrete collapses when the slump 


\begin{tabular}{lcccccc}
\hline & Cement & MHA/RHA & Fine aggregate & Coarse aggregate & SP430 & Water \\
\hline Quantity $\left(\mathrm{Kg} / \mathrm{m}^{3}\right)$ & 603.36 & 64.1 & 857.14 & 754.25 & 10.92 & 182.59 \\
Mix ratio & 1 & 0.106 & 1.41 & 1.24 & 0.02 & 0.302 \\
\hline
\end{tabular}

TABle 1. Design Mix Proportion for MHA and RHA.

\begin{tabular}{llll}
\hline Mineral composition & Cement (\%) & RHA (\%) & MHA (\%) \\
\hline Lime $(\mathrm{CaO})$ & 60 to 67 & 2.10 & 3.30 \\
Silica $\left(\mathrm{SiO}_{2}\right)$ & 17 to 25 & 85.7 & 50.9 \\
Alumina $\left(\mathrm{Al}_{2} \mathrm{O}_{3}\right)$ & 3 to 8 & 0.58 & 28.16 \\
Iron oxide $\left(\mathrm{Fe}_{2} \mathrm{O}_{3}\right)$ & 0.5 to 6 & 1.22 & 5.07 \\
Magnesia $(\mathrm{MgO})$ & 0.1 to 4 & 0.39 & 0.98 \\
Sulphur trioxide $\left(\mathrm{SO}_{3}\right)$ & 1 to 3 & 0.11 & - \\
Loss on ignition $(\mathrm{L} . \mathrm{O} . \mathrm{I})$ & 1.73 & 5.81 & 0.20 \\
Phosphorus $(\mathrm{P})$ & - & 0.35 & - \\
CaSO & - & 0.06 & - \\
Alkalies $\left(\mathrm{Na}_{2} \mathrm{O}+\mathrm{K}_{2} \mathrm{O}\right)$ & 0.5 to 1.3 & 3.52 & 1.99 \\
\hline
\end{tabular}

TABLE 2. Mineral components of cement and millet husk ash.

\begin{tabular}{ll}
\hline Test method & Property \\
\hline Slump flow & Filling ability \\
V-funnel & Filling ability \\
V-funnel at $T_{5 \text { mins }}$ & Segregation resistance \\
L-box & Passing ability \\
\hline
\end{tabular}

TABLE 3. Test methods for SCC [15].

\begin{tabular}{lccc}
\hline \multirow{2}{*}{ Test } & \multirow{2}{*}{ Unit } & \multicolumn{2}{c}{ Typical range of values } \\
\cline { 3 - 4 } & & Minimum & Maximum \\
\hline Slump flow & $\mathrm{mm}$ & 650 & 800 \\
V-funnel & $\mathrm{Sec}$ & 6 & 12 \\
V-funnel at $T_{5 \text { mins }}$ & $\mathrm{Sec}$ & 6 & 15 \\
L-box & $H_{2} / H_{1}$ & 0.8 & 1.0 \\
\hline
\end{tabular}

TABle 4. Acceptance criteria for SCC [15].

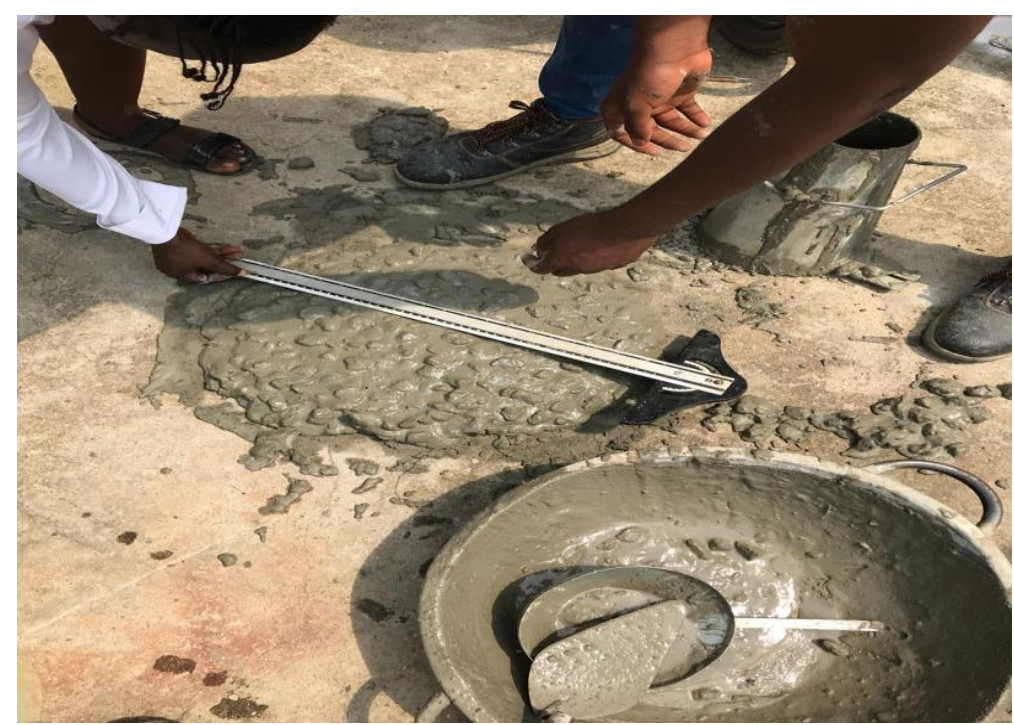

Figure 2. Slump flow measurement of SCC. 
cone is raised. Also, the diameter of the spread of the sample is measured unlike for the NVC, where the height of the concrete is measured after the removal of the slump cone. better flowability is achieved if the diameter of slump spread ranges between 650 and 800 mm. Most SCC mixes produce collapse slumps due the high flowability and self-compacting nature of the concrete as shown in Fig. 22 The water absorption of each concrete mix was estimated from equ. 1 .

$$
\left(\frac{\left(W_{1}-W_{0}\right)}{W_{0}} \times 100\right)
$$

\subsection{WORKABILITY USING V-FUNNEL APPARATUS}

The V-funnel test was developed in Japan and involves the use of a v-shaped funnel shown in Fig. 3. The test is used in the determination of the flowability of the SCC with a maximum coarse aggregate size of $20 \mathrm{~mm}$. Although the measurement of the flowability is the major aim of the v-funnel test, the flowability results are greatly affected by other concrete properties than just the flow.

To carry out the test, the trapdoor was closed and the apparatus was filled completely with about 12 litres of concrete without tamping. The concrete is allowed to flow out under gravity with the trap door opened. The time taken for the flow was measured and recorded.

\subsection{WORKABILITY USING THE L-BOX APPARATUS}

The workability of the SCC using the L-box apparatus is used to check the extent by which the reinforcement is blocking the flow of the concrete. It is an L-shaped rectangular apparatus with a vertical and horizontal parts. The apparatus was filled with about 14 litres of concrete, after which the gate was lifted and the concrete was allowed to flow out freely into the horizontal section. When the concrete stops flowing; the height, $H_{1}$ of the concrete in the vertical section was measured and recorded. Also, the height, $\mathrm{H}_{2}$ of the concrete in the horizontal section was also measured and recorded.

The blocking ratio, $H_{1} / H_{2}$ was then calculated.

If the blocking ratio $H_{1} / H_{2}=1$, it implies a high workability. Generally, a minimum blocking ratio of 0.8 is suggested by the EU research team. Fig. 4 shows the L-box and the execution of the test.

\subsection{Strength test using COMpression TESTING MACHINE}

The load per unit area exerted on the concrete material under test and tending to shorten or reduce its size is called the compressive strength. Cubes of size $100 \times$ $100 \times 100 \mathrm{~mm}$ were tested following the specification of BS EN 12390-3 22. The results will give an idea about the kind of concrete that is being delivered at site. Many industries apply this principle in the quality control of their products. Fig. 5 shows a $2000 \mathrm{kN}$ compression testing machine in action.

By this single test, one can judge whether the process has been done properly or not. Sixteen (16) cubes were cast for each type of concrete (NVC, MHA and RHA). These specimens were cured and tested after 7 days, 14 days, 21 days and 28 days. The Load was applied at a constant rate of $140 \mathrm{~kg} / \mathrm{cm}^{2}$ per minute until the specimen yields. The compressive strength at failure was measured and recorded accordingly.

\subsection{SPlit TENSILE TEST}

This is an indirect test method of determining the tensile resistance of concrete. The test was performed after the 28 days of curing of the specimen. The application of the load on the specimen by the universal testing machine causes a development of tension around the plane containing the applied load. Split tensile test strength was carried out on concrete specimens based on ASTM C496-11 [23] using 75 by $150 \mathrm{~mm}$ cylindrical specimen for the NVC, MHA and RHA. A total of 48 specimens were prepared, 16 for each type. The samples were tested and the load causing the tensile stresses was measured and recorded accordingly.

\subsection{Flexural Strength test USing ASTM C-2930}

A total of 32 beams were cast to perform the flexural strength test (MoR) in an accordance with ASTM C293 / C293M-16 [24] using the centre-point loading system. The test was performed using a digital $100 \mathrm{kN}$ Universal Testing Machine (UTM) at the ABUAD Structures laboratory. Fig. 6 shows the beam specimen being tested using the UTM. The deflection of all tested samples were measured using a dial gauge attached to the UTM with its tip at the central position of the beam. As the specimen is loaded, the value of the load and the corresponding value of deflection are displayed. See Fig. 6

\section{Results And Discussion}

\subsection{Chemical Constituents of mineral ADDITIVES}

Table 5 shows the comparison of the pozzolanic potentials of the MHA and RHA. following the recommendations of ASTM C618 - 78 [25], the RHA had $87.5 \%$ of the combined mineral constituents of silicon oxide, aluminium oxide and iron oxide $\left(\mathrm{SiO}_{2}+\mathrm{Al}_{2} \mathrm{O}_{3}\right.$ $\left.+\mathrm{Fe}_{2} \mathrm{O}_{3}\right)$ while the MHA had $84.13 \%$ of these combinations. These values are both higher than $70 \%$ indicating that the MHA and RHA have a high pozzolanic potentials. But the slight difference in their potentials may be due to the absence of $\mathrm{SO}_{3}$ in the mineral constituents of the MHA. 


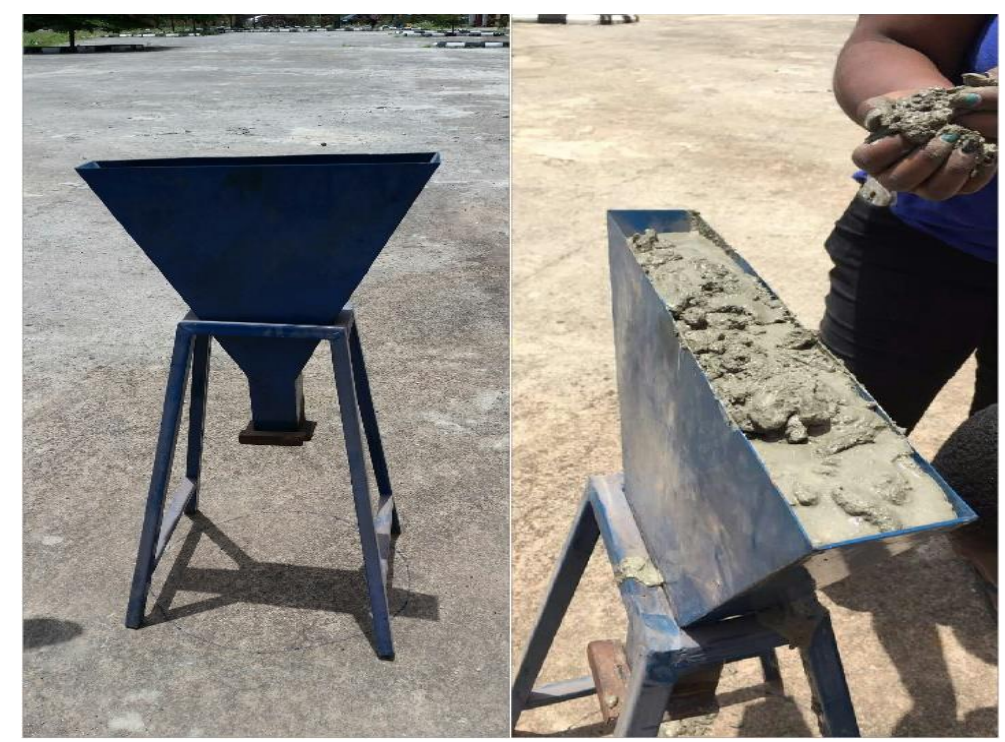

Figure 3. V-funnel apparatus and execution of V-funnel test.

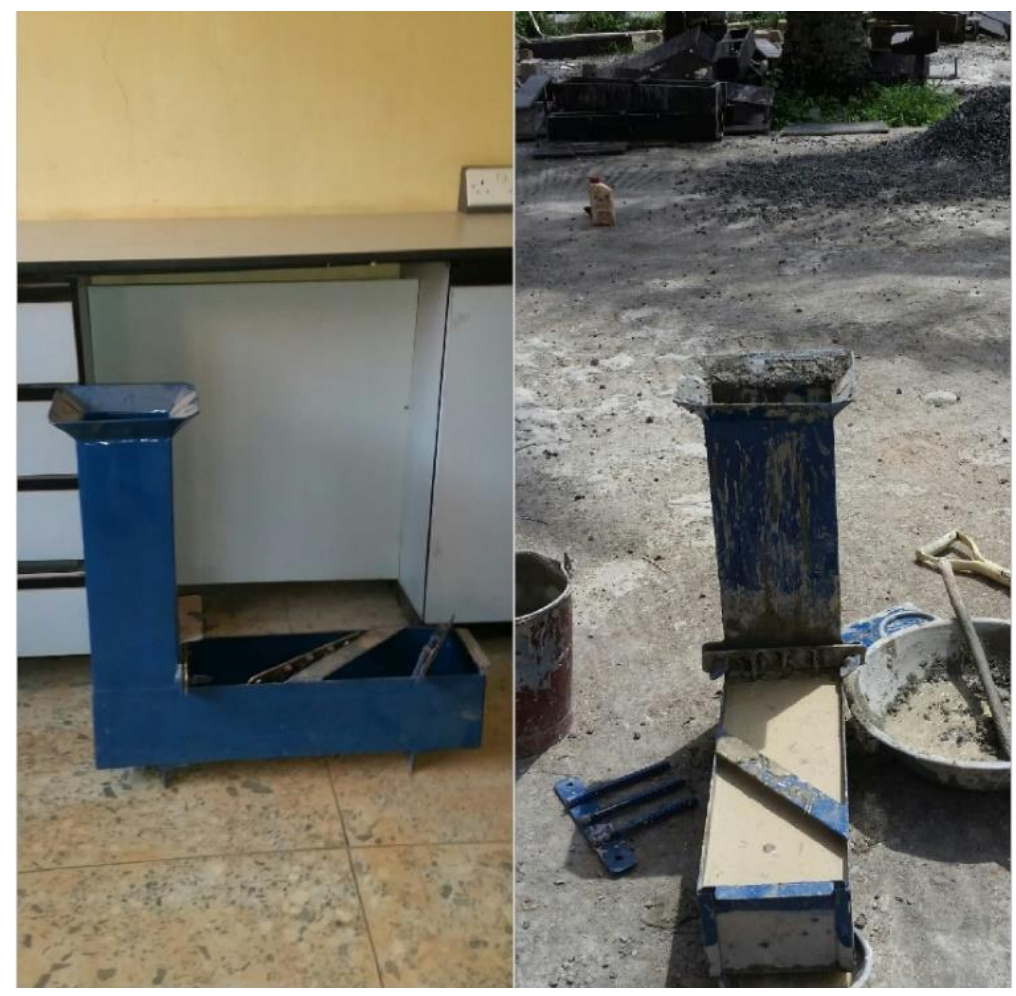

Figure 4. L-box apparatus and execution of L-box test.

\begin{tabular}{lccccc}
\hline Chemical pozzolan (\%) & Class C & Class N & Class $\mathrm{F}$ & RHA & MHA \\
\hline $\mathrm{SiO}_{2}+\mathrm{Al}_{2} \mathrm{O}_{3}+\mathrm{Fe}_{2} \mathrm{O}_{3}$ & $>50$ & $>70$ & $>70$ & 87.5 & 84.13 \\
$\mathrm{SO}_{3}$ & $<4$ & $<5$ & $<5$ & 0.11 & - \\
$\mathrm{MgO}$ & $<5$ & $<5$ & $<5$ & 0.39 & 0.98 \\
$\mathrm{Na}_{2} \mathrm{O}$ & $<1.5$ & $<1.5$ & $<1.5$ & 3.52 & 1.99 \\
Loss on ignition & $<6$ & $<10$ & $<2$ & 5.81 & 0.20 \\
\hline
\end{tabular}

TABle 5. Pozzolanic properties of RHA and MHA in accordance with ASTM C618-78. 


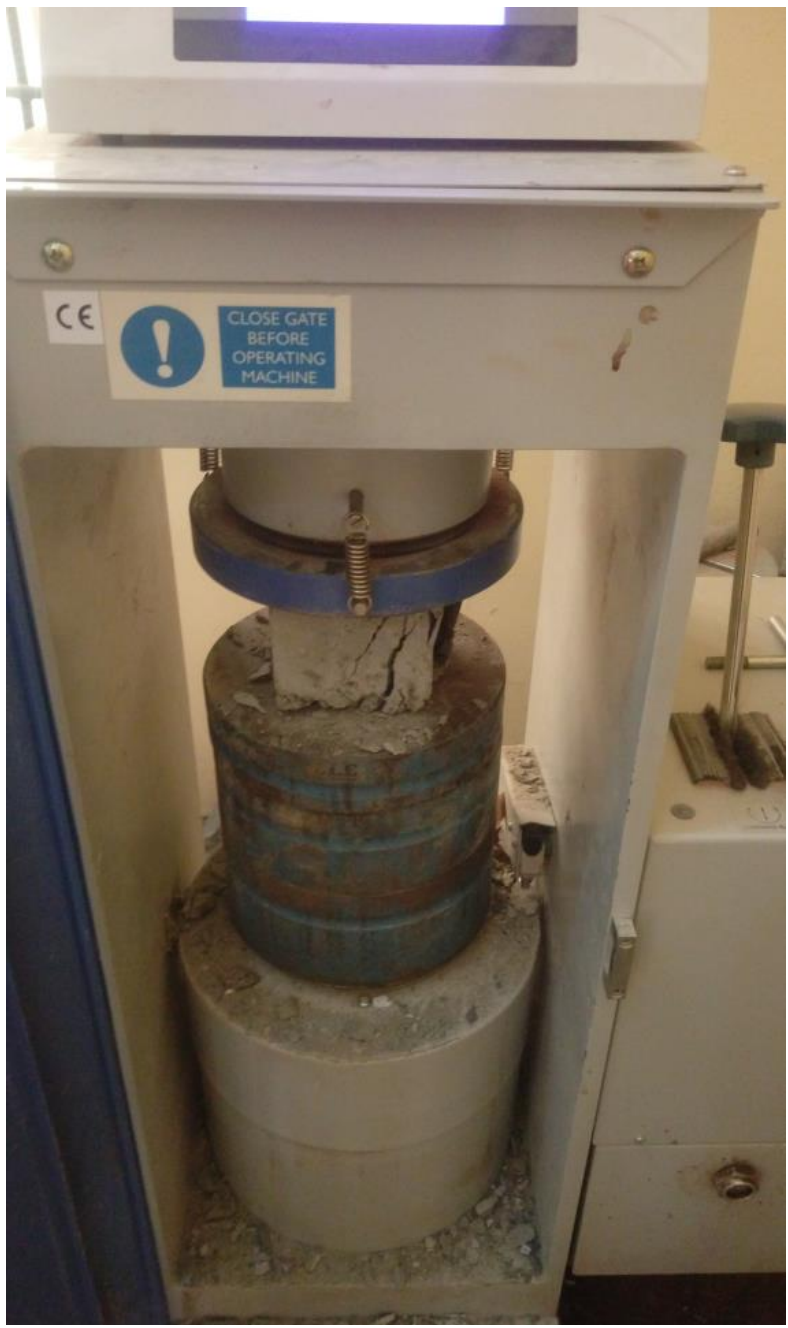

Figure 5. Crushing of concrete cube specimen.

\subsection{Results of the WORKABILITY TEST}

The results of workability tests using the slump cone, V-Funnel and L-Box apparatus are presented in Tables 6 and 7 . These results are also validated using the specifications of EFNARC [18].

The MHA and RHA as an additive in SCC exhibited high slump spread of 748 and $738 \mathrm{~mm}$ respectively. Although, the flowability of the MHA being higher than in the case of the RHA may due to the high percentage of $\mathrm{Na}_{2} \mathrm{O}$ present in the mineral constituents (i.e. $3.52 \%>1.5 \%$ as specified by EFNARC [18. The NVC exhibited a higher flowability than the MHA and RHA. Generally, the results of the workability tests revealed a highly workable concrete for all samples and within the acceptable criteria for SCC.

\subsection{Results of COMPRESSive StREnGth, DENSITY AND ABSORPTION TESTS}

The results of the compressive strength, density and absorption tests of the MHA, RHA and NVC are presented in Tables 8,9 and 10 respectively. The compressive strength for the MHA, RHA and NVC increases with curing days. Their average densities are between $2487.5 \mathrm{~kg} / \mathrm{m}^{3}, 2516.5 \mathrm{~kg} / \mathrm{m}^{3}$ and 2437.5 respectively, with the RHA having the highest density. These values are within the recommendations of [26]. The MHA and RHA showed a promising pozzolanic properties in the concrete mixes.

With reference to Table 8, 9 and 10, the SCC with the MHA as an additive had about $13.2 \%$ higher compressive strength values over the RHA and NVC at 28 days of curing. The higher compressive strength recorded with the use of the MHA as a mineral additive, and judging from the chemical composition, may be due to the higher alumina $\left(\mathrm{Al}_{2} \mathrm{O}_{3}\right)$ and lime $(\mathrm{CaO})$ contents present in the MHA as compared to the RHA. In terms of water absorption, the MHA has the highest absorption capacity $(3.7 \%)$ with the RHA recording the lowest $(2.5 \%)$. According to "the concrete Society" [27], water absorption should be in the range of 6-7\%. All samples tested have satisfied this requirement.

\subsection{Results of the SPlit tensile test}

The Tensile strength for the NVC, RHA and MHA increases with an increase in curing days as shown in Fig. 7. The MHA shows an improvement in strength over the RHA and NVC due to the presence of pozzolanic effect of silica oxide, alumina and lime in the ash, thereby enhancing the cementitious reaction of the concrete mixes. Fig. 7 also showed that the SCC with the MHA as additive yielded higher tensile strength than the RHA and NVC at 28 days of curing. The range is about $17.2-22.2 \%$ higher than the tensile strength recorded by the RHA and NVC. This results are also in an accordance with other tests carried out.

\subsection{Results of FleXuRAL StREngth test (MODUlus OF RUPTURE)}

The Modulus of Rupture (MoR) of the SCC with the MHA and RHA as an additive increase with curing age. Their maximum Load-Deflection curve indicates a similar trend with that of the NVC. The deflection is generally higher with the MHA and RHA as mineral additives than that of the NVC. The maximum load $(F)$ and MoR of the MHA and RHA are $19.8 \%$ and $19.2 \%$ higher than that of NVC at 28 days curing respectively. The MHA and RHA have the same MoR $\left(10.4 \mathrm{~N} / \mathrm{mm}^{2}\right)$ at 28 days of curing. The deflection curve of the SCC containing the MHA and RHA seemed to be higher than that of the NVC. Although all are within the allowable value of span/effective depth ratio. Figs. 8,9 and 10 shows the plots of the maximum load, MoR and deflection for the MHA, RHA and NVC respectively.

\section{Conclusions}

This research presents an experimental investigation of the pozzolanic potentials of the MHA and RHA as mineral additives in the SCC. The summary of the experimental program is summarized below: 


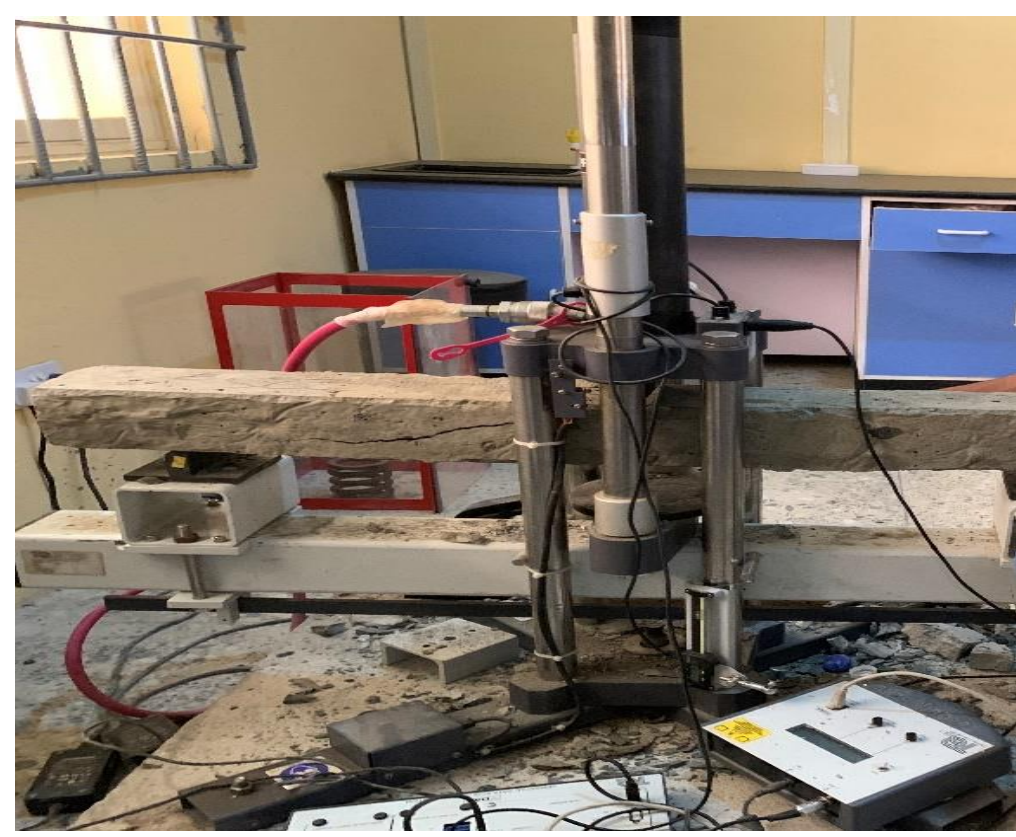

FiguRE 6. Flexural strength test of beam specimen using $100 \mathrm{kN}-\mathrm{UTM}$.

\begin{tabular}{lccccc}
\hline SCC grade & Aggregate size $(\mathrm{mm})$ & Additive & $D_{1}(\mathrm{~mm})$ & $D_{2}(\mathrm{~mm})$ & Slump value \\
\hline M70 & 20 & MHA & 755 & 741 & 748 \\
M70 & 20 & RHA & 740 & 736 & 738 \\
M70 & 20 & NVC & 761 & 757 & 759 \\
\hline
\end{tabular}

TABLE 6. Slump cone test at $10 \%$ MHA and RHA.

\begin{tabular}{lccccc}
\hline Type of test & MHA & NVC & RHA & \multicolumn{2}{c}{ Code range } \\
\cline { 5 - 6 } & & & & Minimum & Maximum \\
\hline V-funnel & 9 secs & $10 \mathrm{sec}$ & 9 secs & 6 secs & 12 secs \\
L-box $\left(T=\frac{H_{2}}{H_{1}}\right)$ & $\frac{12.4}{13.0}=0.954$ & $\frac{13.8}{14.5}=0.950$ & $\frac{14.6}{15.7}=0.930$ & 0.8 & 1.0 \\
\hline
\end{tabular}

TABLE 7. Results of V-funnel and L-box tests at $10 \%$ MHA and RHA.

\begin{tabular}{ccccccc}
\hline No. of days & $W_{0}(\mathrm{~kg})$ & $W_{1}(\mathrm{~kg})$ & Absorption $(\%)$ & Force $(\mathrm{kN})$ & $C . S(\mathrm{MPa})$ & Density $\left(\mathrm{kg} / \mathrm{m}^{3}\right)$ \\
\hline 7 & 2.45 & 2.47 & 0.8 & 507.7 & 50.77 & 2450 \\
14 & 2.43 & 2.48 & 2.1 & 664.6 & 65.42 & 2480 \\
21 & 2.44 & 2.50 & 2.5 & 716.7 & 71.67 & 2500 \\
28 & 2.43 & 2.52 & 3.7 & 839.0 & 83.9 & 2520 \\
\hline
\end{tabular}

TABLE 8. Absorption, density and compressive strength of SCC at $10 \%$ MHA.

\begin{tabular}{ccccccc}
\hline No. of days & $W_{0}(\mathrm{~kg})$ & $W_{1}(\mathrm{~kg})$ & Absorption $(\%)$ & Force $(\mathrm{kN})$ & C.S $(\mathrm{MPa})$ & Density $\left(\mathrm{kg} / \mathrm{m}^{3}\right)$ \\
\hline 7 & 2.56 & 2.60 & 1.6 & 739.5 & 49.3 & 2560 \\
14 & 2.44 & 2.46 & 0.8 & 826.5 & 55.1 & 2440 \\
21 & 2.59 & 2.67 & 2.8 & 1042.5 & 69.5 & 2593 \\
28 & 2.47 & 2.47 & 1.6 & 1092.0 & 72.8 & 2473 \\
\hline
\end{tabular}

TABLE 9. Absorption, density and compressive strength of SCC at $10 \%$ RHA. 


\begin{tabular}{ccccccc}
\hline No. of days & $W_{0}(\mathrm{~kg})$ & $W_{1}(\mathrm{~kg})$ & Absorption $(\%)$ & Force $(\mathrm{kN})$ & $C . S(\mathrm{MPa})$ & Density $\left(\mathrm{kg} / \mathrm{m}^{3}\right)$ \\
\hline 7 & 2.28 & 2.31 & 1.3 & 395.3 & 39.5 & 2310 \\
14 & 2.41 & 2.45 & 1.7 & 527.4 & 52.7 & 2450 \\
21 & 2.40 & 2.49 & 3.8 & 661.4 & 66.1 & 2490 \\
28 & 2.44 & 2.50 & 2.5 & 731.7 & 72.8 & 2500 \\
\hline
\end{tabular}

TABLE 10. Absorption, density and compressive strength of NVC (0\% additive).

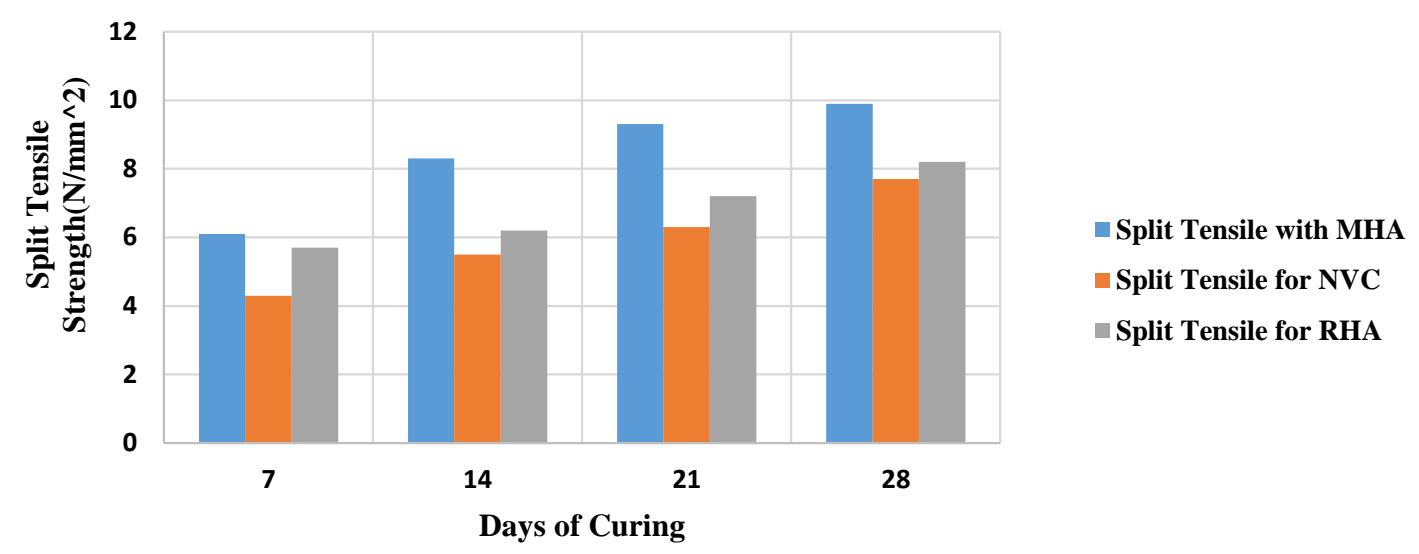

FigURE 7. Variation of split tensile strength of SCC with MHA, RHA and NVC at grade M70.

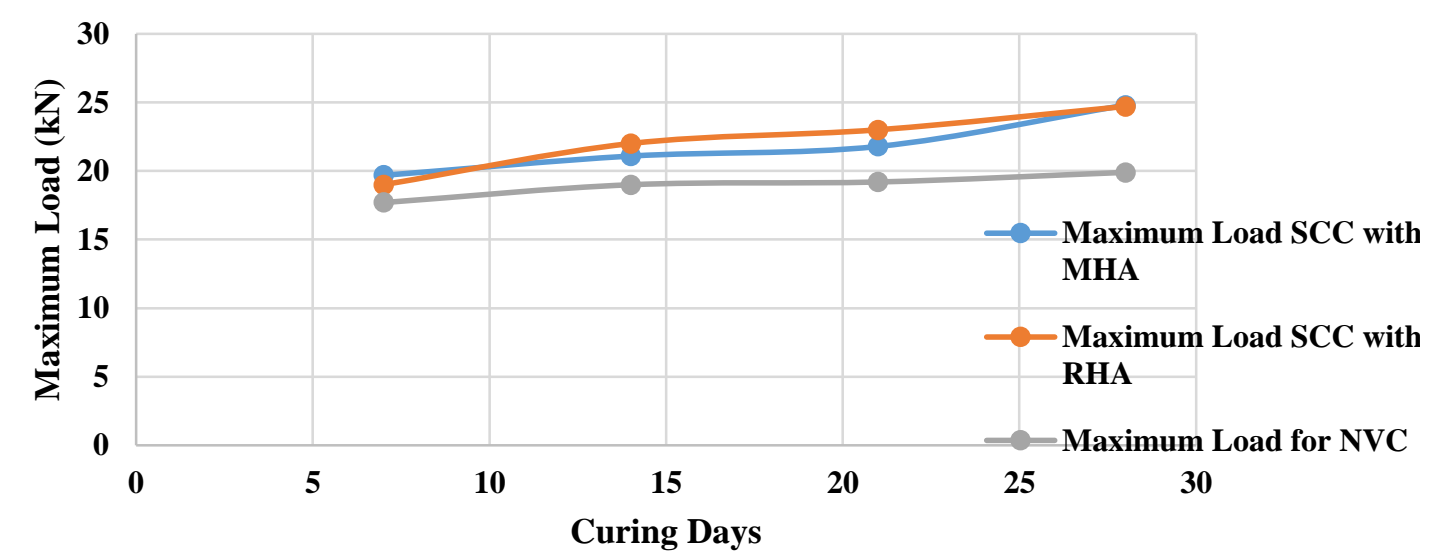

Figure 8. Plot of maximum load of SCC with MHA, RHA and NVC against curing days.

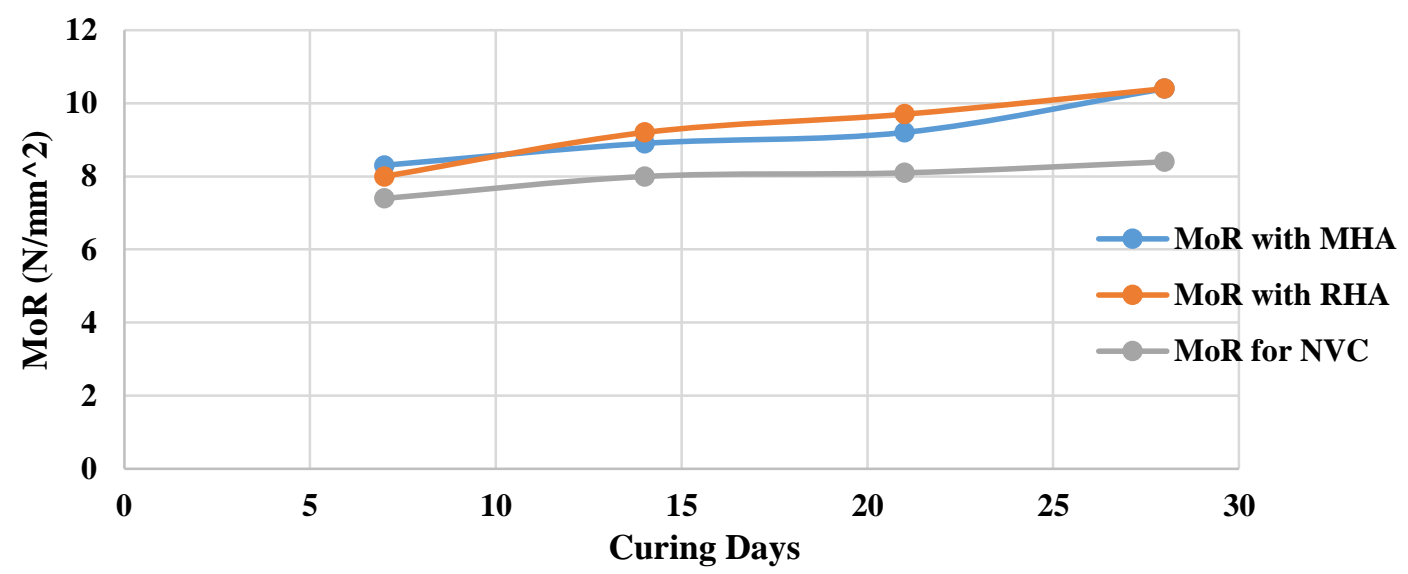

Figure 9. Plot of MoR for SCC with MHA, RHA and NVC against curing days. 


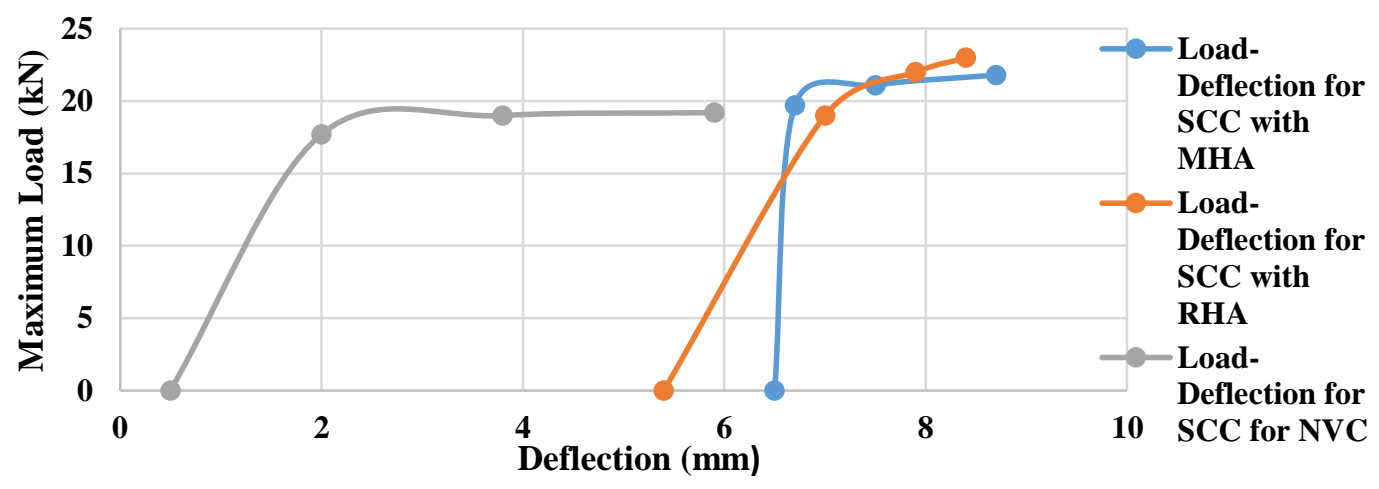

Figure 10. Plot of maximum load against deflection for SCC with MHA, RHA and NVC.

(1.) The mineral constituents $\left(\mathrm{SiO}_{2}+\mathrm{Al}_{2} \mathrm{O}_{3}+\right.$ $\left.\mathrm{Fe}_{2} \mathrm{O}_{3}\right)$ of the MHA and RHA are greater than $70 \%$ indicating their potentials as mineral additives in the SCC.

(2.) The water absorption of both the MHA and RHA are within the specified standard and as such; adequate for use as mineral additives in the SCC.

(3.) Workability tests using the L-box test, V-funnel and slump cone for the SCC for the MHA and RHA as an additive showed that they are sufficiently workable like the NVC and revealed a workable concrete within the required specification.

(4.) The addition of the MHA and RHA as mineral additives in the SCC does not reduce the density of the SCC below the average specified value of $2400 \mathrm{~kg} / \mathrm{m}^{3}$. All densities are within the acceptable range.

(5.) Their compressive strengths are considerably higher than that of the NVC of the same grade M70. The tensile strength test for MHA as an additive revealed a higher resistance to tension than that of the RHA and NVC.

(6.) The MoR of MHA and RHA revealed a higher modulus of rupture than the NVC. This also indicates a better quality control than NVC.

MHA and RHA should not be discarded as a waste material since this research has proven them to be of high pozzolanic properties. Their use can help to reduce environmental waste and costs of disposal of such waste. The MHA and RHA are environmental waste that can be obtained easier than other additives used for the SCC. They can be explored as mineral materials for the SCC in the Building and Construction Industry.

\section{ACKNOWLEDGEMENTS}

Thanks to ABUAD Concrete and Structures laboratory.

\section{REFERENCES}

[1] J. Wasiu, O. Agbawhe, Z. Tuleun. The effect of calcium carbonate filler on self-compacting concrete using different aggregate sizes. European Journal of
Engineering Research and Science 4:9 - 16, 2019 DOI:10.24018/ejers.2019.4.9.1485

[2] D. A. John. Concrete Petrography: A Handbook of Investigative Techniques. Wiley \& Sons, New York, 1998.

[3] K. Johansen, T. A. Hammer. Drying Shrinkage of Norwegian Self-Compacting Concrete. SINTEF, Trondheim, 2002.

[4] H. E. Elyamany, A. E. M. Abd Elmoaty, B. Mohamed. Effect of filler types on physical, mechanical and microstructure of self compacting concrete and flow-able concrete. Alexandria Engineering Journal 53(2):295 307, 2014. DOI:10.1016/j.aej.2014.03.010

[5] S. H. Kosmatka. Design and Control of Concrete Mixtures. Cement Association of Canada, Ottawa, 5th edn., 2002.

[6] N. Nagamoto, K. Ozawa. Mixture proportions of self-compacting high performance concrete. In $A C I$ international, vol. SP - 172, p. 623 - 636. 1997.

[7] S. A. Rizwan, T. A. Bier. Blends of limestone powder and fly-ash enhance the response of self-compacting mortars. Construction and Building Materials 27(1):398 - 403, 2012. DOI:10.1016/j.conbuildmat.2011.07.030.

[8] G. Sua-iam, N. Makul. Utilization of limestone powder to improve the properties of self-compacting concrete incorporating high volumes of untreated rice husk ash as fine aggregate. Construction and Building Materials 38:455 - 464, 2013. DOI:10.1016/j.conbuildmat.2012.08.016

[9] M. Palanisamy, P. Kolandasamy, P. Awoyera, et al. Permeability properties of lightweight self-consolidating concrete made with coconut shell aggregate. Journal of Materials Research and Technology 9(3):3547 - 3557, 2020. DOI:10.1016/j.jmrt.2020.01.092

[10] O. A. U. Uche, M. Adamu, M. A. Bahuddeen. Influence of millet husk ash (MHA) on the properties of plain concrete. Epistemic In Science, Engineering And Technology Journal 2:68 - 73, 2012.

[11] O. A. U. Uche, J. A. Ahmed. Effect of millet husk ash on index properties of marginal lateritic soil. Research Journal in Engineering and Applied Sciences 5:365 - 369, 2013.

[12] M. T. Abdulwahab, O. A. U. Uche, G. Suleiman. Mechanical properties of millet husk ash bitumen stabilized soil block. Nigerian Journal of Technological Development 14:34 - 38, 2017. DOI:10.4314/njtd.v14i1.5 
[13] S. A. Zareei, F. Ameri, F. Dorostkar, M. Ahmadi. Rice husk ash as a partial replacement of cement in high strength concrete containing micro silica:

Evaluating durability and mechanical properties. Case Studies in Construction Materials 7:73 - 81, 2017. DOI:10.1016/j.cscm.2017.05.001

[14] R. I. Umasabor, J. O. Okovido. Fire resistance evaluation of rice husk ash concrete. Heliyon 4(12):e01035, 2018. DOI:10.1016/j.heliyon.2018.e01035

[15] B. Arun Kumar, G. Sangeetha, A. Srinivas, et al. Models for predictions of mechanical properties of lowdensity self-compacting concrete prepared from mineral admixtures and pumice stone. In Soft Computing for Problem Solving, pp. 677 - 690. Springer Singapore, Singapore, 2020. DOI:10.1007/978-981-15-0184-5_58

[16] N. Su, K.-C. Hsu, H.-W. Chai. A simple mix design method for self-compacting concrete. Cement and Concrete Research 31(12):1799 - 1807, 2001. DOI:10.1016/S0008-8846(01)00566-X

[17] C. Druta. Tensile Strength and Bonding Characteristics of Self-Compacting Concrete. Polytechnic University of Bucharest, 2003.

[18] B. Poulson. Specification and guidelines for self-compacting concrete. Tech. rep., European Federation of Producers and Applicators of Specialist Products for Structures, Hampshire, U.K., 2002.

[19] BS EN 12350-8: Testing Fresh Concrete. Self-Compacting Concrete. Slump-Flow Test. Standard, British Standards Institution, London, 2010.
[20] BS EN 12350-9: Testing Fresh Concrete. Self-Compacting Concrete. V-Funnel Test. Standard, British Standards Institution, London, 2010.

[21] BS EN 12350-10: Testing Fresh Concrete. Self-Compacting Concrete. L Box Test. Standard, British Standards Institution, London, 2010.

[22] BS EN 12390-3: 2019: - Testing Hardened Concrete Part 3: Compressive Strength of Test Specimens. Standard, British Standards Institution, London, 2002.

[23] ASTM C496-11: Spliting Tensile Strength of Cylindrical Concrete Specimens). Standard, American Society for Testing and Materials, West Conshohocken, 2011.

[24] ASTM C293/C293M-16 - Standard Test Method for Flexural Strength of Concrete (Using Simple Beam with Center-Point Loading). Standard, American Society for Testing and Materials, West Conshohocken, 2016.

[25] ASTM C618 - 78: Standard Specification for Fly Ash and Raw Or Calcined Natural Pozzolan For Use As A Mineral Admixture In Portland Cement Concrete. Standard, American Society for Testing and Materials, West Conshohocken, 1978.

[26] A. M. Neville. Properties of concrete. 3rd edn.

[27] The Concrete Society. Water absorption for lightweight concrete. https://www.concrete.org.uk Accessed: 9 December 2019. 